\title{
Meningkatkan Kesadaran Respek Siswa Sekolah Dasar dengan Biblioedukasi
}

\author{
(Enhancing Elementary School Students' Awareness of Respect through Biblio \\ Education)
}

\author{
Innaha Fahrish Safitri*, Dany Moenindyah Handarini, Andi Mappiare-AT \\ 1Universitas Negeri Malang, Jl. Semarang No. 5 Malang, Jawa Timur, Indonesia \\ *Penulis korespondensi, Surel: innahafahrish25@gmail.com
}

Paper received: 1st-Oct-2020; revised: 7th-Jan-2021; accepted: 10th-Jan-2021

\begin{abstract}
Respect contributes to restraining the frequently occur acts of violence. Biblio education belongs to one of the means to establish respect. This study aims to investigate the efficacy of Biblio Education in improving elementary students' awareness of respect. This quantitative study employs an equivalent time-series design with ten subjects from State Elementary School of Gadingkasri, selected through purposive sampling. It used Biblio Education treatment in eight meetings. A validated and reliable respect awareness scale was used as the measuring instrument. The data were analyzed using non-parametric data analysis of the Wilcoxon Signed Rank Test. The results reveal that the 1-4 treatments carry no effect on students' awareness of respect. Its impact on students' awareness of respect is observed in treatments 5-8. Comprehensively, Biblio Education is sufficient to enhance elementary school students' awareness of respect.
\end{abstract}

Keywords: biblio education; awareness of respect; elementary school students'

\begin{abstract}
Abstrak
Sikap respek memberi kontribusi dalam pencegahan kekerasan yang kian marak dewasa ini. Salah satu cara mengembangkan sikap respek adalah melalui biblioedukasi. Penelitian ini bertujuan untuk menguji keefektifan biblioedukasi untuk meningkatkan kesadaran akan respek pada siswa sekolah dasar (SD). Penelitian kuantitatif ini menggunakan rancangan equivalent time series design. Subjek penelitian sebanyak sepuluh siswa kelas lima SD Negeri Gadingkasri dan dipilih menggunakan teknik purposive sampling. Treatment dalam penelitian ini ialah biblioedukasi sebanyak delapan pertemuan. Alat ukur yang digunakan yaitu skala kesadaran akan respek yang telah diuji validitas dan reliabilitasnya. Teknik analisis hasil yang digunakan yaitu analisis data non parametrik dengan statistik uji Wilcoxon Signed Rank Test. Hasil penelitian menunjukkan bahwa treatment ke 1-4 tidak memberikan pengaruh pada skor kesadaran akan respek siswa. Sedangkan treatment ke 5-8 memberikan pengaruh pada skor kesadaran akan respek siswa. Secara keseluruhan, biblioedukasi efektif untuk meningkatkan kesadaran akan respek siswa SD.
\end{abstract}

Kata kunci: biblioedukasi; kesadaran akan respek; siswa SD

\section{Pendahuluan}

Manusia sebagai makhluk sosial, tak lepas dari interaksi dengan orang lain dalam kehidupan seharai-hari. Oleh karenanya, harus ada kesadaran akan respek dalam diri individu. Kesadaran akan respek merupakan kesadaran akan menghormati dan menghargai. Rasa hormat dalam diri seseorang yaitu dengan menunjukkan penghargaan kita terhadap harga diri orang lain atau hal lain selain diri kita (Lickona, 2009). Apabila individu memiliki kesadaran akan respek yang tinggi maka ia akan mampu berkontribusi dan mewujudkan kehidupan damai dengan menunjukkan penghormatan dan pengharga- 
annya kepada orang lain. Sebaliknya, apabila individu memiliki kesadaran akan respek rendah maka tidak akan mampu berkontribusi dalam mewujudkan kehidupan damai.

Saat ini, kesadaran akan respek dalam diri individu nampaknya mulai menurun. Hal ini terlihat dari banyaknya kasus-kasus yang terjadi pada generasi muda. Berdasarkan hasil wawancara dengan salah satu guru SDN Gadingkasri pada 2019, diperoleh informasi bahwa menurunnya kesadaran akan respek siswa terlihat pada kasus siswa mengolokolok antar teman hingga menjadikan nama orangtua sebagai bahan olokan, tidak menyimak penjelasan guru di kelas, serta pemalakan antar siswa. Pada akhir tahun 2018, terjadi pengeroyokan oleh siswa di salah satu sekolah di Kediri, penyebabnya adalah gol bunuh diri saat bermain sepak bola pada jam istirahat (Sangaji, 2019). Pada tahun yang sama, terjadi perkelahian oleh siswa salah satu sekolah di Garut, hingga menewaskan salah satu siswa (Karang, 2018). Jika tidak ada upaya preventif yang dilakukan, maka tidak menutup kemungkinan kasus-kasus menurunnya kesadaran akan respek akan terus bertambah.

Salah satu usaha preventif yang dapat dilakukan adalah dengan menumbuhkan kesadaran akan respek dalam diri individu sejak dini. Sejalan dengan fungsi pendidikan yaitu mengembangkan dan membentuk watak serta peradaban bangsa yang bermartabat dalam rangka mencerdaskan kehidupan bangsa (Kemendikbud, 2003), maka penyelenggara pendidikan di sekolah dasar mempunyai tanggung jawab besar dalam mengem-bangkan kesadaran akan respek pada diri siswa sejak dini. Lebih spesifik, ini menjadi tugas konselor di sekolah dasar dalam membantu siswa mengembangkan diri secara optimal, termasuk kesadaran akan respek. Namun, realitanya pada jenjang sekolah dasar sangat jarang dijumpai adanya konselor di sekolah. Pada kondisi sekolah yang belum memiliki konselor maka penyelenggaraan layanan bimbingan dan konseling dapat ditugaskan kepada guru kelas (Kemendikbud, 2016).

Biblioedukasi sebagai metode bimbingan yang dapat dilaksanakan oleh konselor maupun guru kelas. Biblioedukasi atau biasa disebut dengan biblioterapi adalah salah satu teknik dalam bimbingan kelompok yang memanfaatkan bahan bacaan sebagai medianya. Implementasi biblioedukasi di sekolah seharusnya dilakukan oleh guru yang berkolaborasi dengan personil sekolah seperti konselor sekolah dan pustakawan sekolah. Konselor sekolah dapat membantu guru untuk menemukan cara yang tepat dalam mengidentifikasi masalah beserta solusi dari permasalahan yang sedang dialami siswa. Sedangkan pustakawan sekolah dapat membantu guru dalam mengidentifikasi dan memiliki buku atau bacaan yang sesuai. Namun tidak semua sekolah dasar memiliki konselor maupun pustakawan sehingga guru yang menjadi satu-satunya tempat bagi siswa untuk mengadukan masalahnya, harus mampu memilih dan menemukan strategi yang tepat untuk membantu siswa (Herlina, 2013).

Tujuan biblioedukasi yaitu: (1) memberikan informasi tentang masalah; (2) memberikan insight tentang masalah; (3) menstimulasi diskusi tentang masalah; (4) mengkomunikasikan nilai-nilai dan sikap-sikap baru; (5) menciptakan suatu kesadaran awareness bahwa orang lain berhasil mengatasi masalah yang mirip; dan (6) memberikan solusi atas permasalahan (Herlina, 2013). Dari tujuan-tujuan tersebut, diharapkan siswa dapat terbantu secara maksimal dalam memperoleh kesadaran akan respek guna mencapai 
perkembangan diri yang optimal. Penelitian lain mengenai keefektifan bacaan (biblio) telah banyak dilakukan di berbagai setting untuk menangani masalah kesadaran, seperti penelitian yang menyatakan bahwa bibliotherapy dan cinemaeducation sama-sama dapat meningkatkan multicultural awareness siswa sekolah menengah atas (Masri, 2016). Penelitian lain menunjukkan bahwa bibliokonseling efektif untuk meningkatkan kesadaran toleransi siswa sekolah menengah pertama (Kamaningtyas, 2012). Penelitian lain juga menunjukkan bahwa bibliokonseling efektif untuk meningkatkan kesadaran bertanggung jawab siswa SMP (Mufidah, 2011). Tujuan penelitian ini adalah menguji keefektifan biblioedukasi untuk meningkatkan kesadaran akan respek pada siswa SD.

\section{Metode}

Metode yang digunakan dalam penelitian ini adalah kuantitatif dengan rancangan penelitian within group or individual design dengan bentuk equivalent time series design. Subjek dalam penelitian ini adalah siswa kelas V SDN Gadingkasri sebanyak sepuluh siswa. Pemilihan subjek dilakukan dengan menggunakan metode purposive sampling. Syarat subjek penelitian adalah siswa tersebut tercatat sebagai siswa kelas V SDN Gadingkasri dan memiliki skor kesadaran akan respek rendah. Treatment dilakukan sebanyak delapan kali dan test sebanyak tiga kali. Awal penelitian dimulai dengan melancarkan tes 1 (pretest) kemudian dilakukan treatment berupa biblioedukasi sebanyak empat kali. Materi bacaan dalam treatment biblioedukasi 1-4 berisi tentang kesadaran akan respek kepada diri. Setelah itu, dilakukan tes 2 (posttest 1). Kemudian dilanjut dengan pemberian treatment biblioedukasi ke 5-8. Materi bacaan dalam treatment biblioedukasi ke 5-8 berisi tentang kesadaran akan respek kepada orang lain. Terakhir, dilancarkan tes 3 (posttest 2).

Terdapat dua instrumen yang digunakan dalam penelitian ini, yaitu instrumen perlakuan dan instrumen pengumpulan data. Instrumen perlakukan berupa panduan biblioedukasi untuk meningkatkan kesadaran akan respek pada siswa SD. Sedangkan instrumen pengumpulan data berupa skala kesadaran akan respek 1, 2 dan 3. Skala kesadaran akan respek ini adalah skala paralel dengan butir pernyataan yang berbeda dan tingkat kesulitan yang sama. Masing-masing skala terdiri dari 22 butir pernyataan. Di dalamnya, terdapat pernyataan favourable dan unvafourable. Skala kesadaran akan respek ini dikembangkan berdasarkan teori kesadaran menurut Zeman dan teori respek menurut Lickona. Skala kesadaran akan respek ini diuji validitas dan reliabilitasya. Uji validitas dilakukan dengan validitas konstruk oleh ahli bimbingan dan konseling serta uji statistik korelasi pearson product moment. Sedangkan uji reliabilitasnya dilakukan dengan uji statistik Alpha Cronbach. Teknik analisis data dalam penelitian ini menggunakan uji wilcoxon.

\section{Hasil dan Pembahasan}

\subsection{Hasil}

Data hasil penelitian diperoleh melalui penyebaran instrumen. Pada tes 1 (pretest) dilancarkan instrumen kesadaran akan respek 1 dan diperoleh sebanyak sepuluh siswa yang mempunyai skor terendah. dua siswa dengan skor awal "sedang", delapan siswa dengan skor awal "tinggi". Sepuluh siswa inilah yang menjadi subjek dalam penelitian. Setelah tes 1 dilancarkan, kemudian dilakukan treatment berupa biblioedukasi sebanyak empat kali dengan 
materi kesadaran akan respek kepada diri. Kemudian dilakukan pengukuran kembali yaitu tes 2 menggunakan instrumen kesadaran akan respek 2 . Hasil tes 2 menunjukkan adanya perubahan skor kesadaran akan respek. Perubahan tersebut berupa peningkatan skor pada 6 siswa, skor tetap pada satu siswa, dan penurunan skor pada tiga siswa.

Setelah itu, dilakukan treatment berupa biblioedukasi sebanyak empat kali dengan materi kesadaran akan respek kepada orang lain. Setelah treatment yang ke delapan selesai dilaksanakan. Kemudian dilakukan pengukuran kembali menggunakan instrumen kesadaran akan respek 3. Berdasarkan hasil tes 3, terdapat perubahan skor kesadaran akan respek. Perubahan tersebut berupa peningkatan skor pada seluruh siswa hingga mencapai kriteria "Sangat Tinggi". Pada gambar 1 disajikan grafik perubahan skor yang terjadi pada subjek selama penelitian.

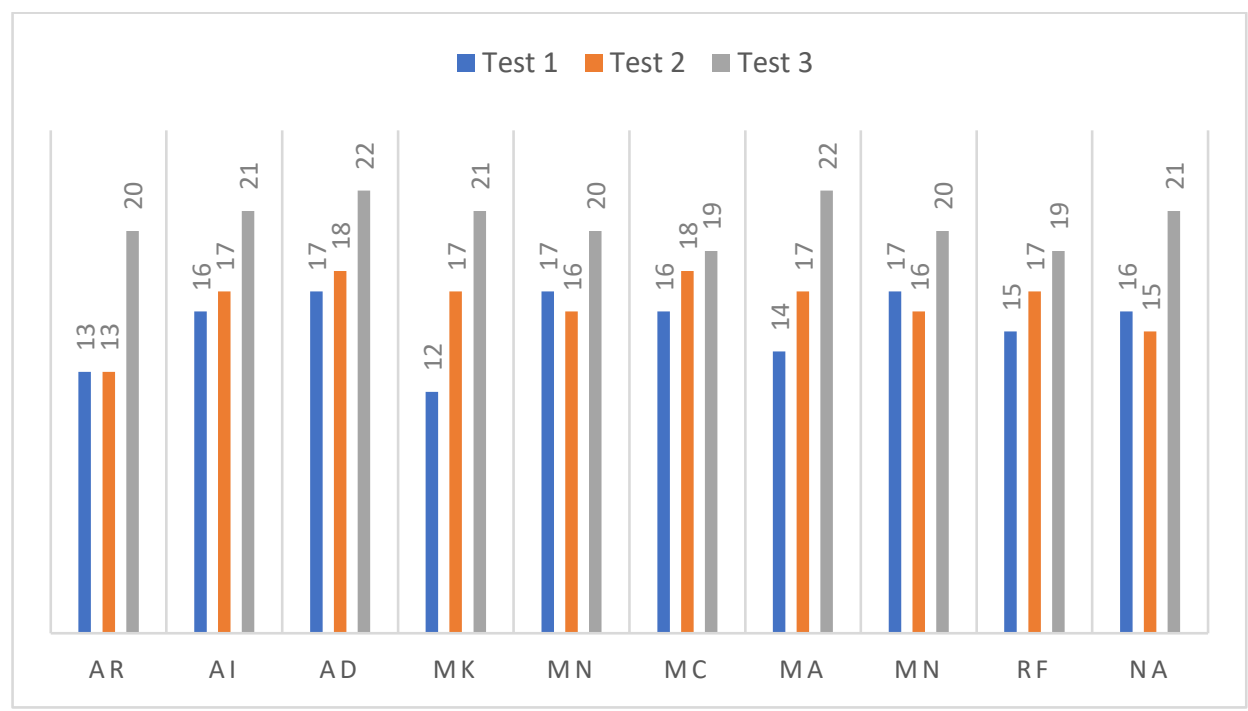

Gambar 1. Grafik Perubahan Skor Tes 1, Tes 2 dan Tes 3

Berdasarkan Gambar 1, dapat dilihat adanya perubahan skor pada subjek dari tes 1 ke tes 2 maupun dari tes 2 ke tes 3 . Setelah dilakukan uji Wilcoxon, tes 1 dan tes 2 menunjukkan angka Asymp. Sig. (2-tailed) 0,1 lebih besar dari 0,05 atau $\mathrm{H}_{0}$ diterima dan $\mathrm{H}_{1}$ ditolak. Artinya, treatment ke 1-4 tidak memberikan pengaruh dalam meningkatkan kesadaran akan respek siswa. Uji Wilcoxon pada tes 2 dan tes 3 menunjukkan angka Asymp. Sig. (2-tailed) 0,005 lebih kecil dari 0,05 atau $\mathrm{H}_{0}$ ditolak dan $\mathrm{H}_{1}$ diterima. Artinya, treatment ke 5-8 memberikan pengaruh dalam meningkatkan kesadaran akan respek siswa. Sedangkan, Uji Wilcoxon pada tes 1 dan tes 3 menunjukkan angka Asymp. Sig. (2-tailed) 0,005 lebih kecil dari 0,05 atau $\mathrm{H}_{0}$ ditolak dan $\mathrm{H}_{1}$ diterima. Artinya, biblioedukasi memberikan pengaruh untuk meningkatkan kesadaran akan respek siswa.

\subsection{Pembahasan}

Berdasarkan analisis data hasil tes 1 dan 2, menunjukkan bahwa treatment biblioedukasi ke 1-4 tidak efektif untuk meningkat kesadaran akan respek pada siswa SD. Hal ini dibuktikan dengan adanya penurunan skor pada tiga subjek, tidak adanya perubahan skor pada satu subjek dan peningkatan skor pada enam subjek. Terjadinya penurunan skor dan skor tetap dikarenakan pada saat pelancaran tes 2 , subjek belum memperolah treatment mengenai 
kesadaran akan respek kepada orang lain. Hal ini tidak sejalan dengan instrumen kesadaran akan respek yang digunakan pada tes 2 . Butir-butir pernyataan pada tes 2 digunakan untuk mengukur kesadaran akan respek kepada diri dan orang lain.

Pada saat pelancaran tes 2 , siswa belum memperoleh persepsi yang utuh mengenai respek kepada orang lain. Persepsi adalah sebuah efek kombinasi dari informasi yang diterima sistem sensorik dengan pengetahuan yang telah dipelajari (Solso, MacLin, \& MacLin, 2005). Pada saat subjek membaca materi bacaan biblioedukasi mengenai respek kepada diri, persepsi yang diperoleh oleh masing-masing subjek dapat berbeda-beda tergantung sistem sensorik yang bekerja (indera penglihatan) dan pengetahuan siswa. Kejadian-kejadian sensorik yang terjadi selama proses pemberian treatment kemudian diproses sesuai dengan pengetahuan yang dimiliki oleh subjek tentang dunia, budaya bahkan pengharapan (Solso et al., 2005).

Pengetahuan yang telah dimiliki sebelumnya pada masing-masing subjek pastilah berbeda-beda. Selain itu, perbedaan atensi dari masing-masing subjek pada saat treatment berlangsung juga sangat berpengaruh terhadap pemahaman yang diperoleh subjek. Inilah yang menyebabkan kesadaran akan respek kepada orang lain yang diharapkan ada pada diri subjek belum sepenuhnya terbentuk, karena subjek memang belum memperoleh stimulus serta penguatan yang ada pada materi bacaan respek kepada orang lain. Hal ini juga yang mendasari adanya perbedaan skor yang diperoleh subjek pada tes 2 . Dengan demikian, ketidaktepatan prosedural dalam penelitian berpengaruh besar pada ketidakefektifan treatment 1-4.

Analisis data hasil tes 2 dan tes 3 menunjukkan bahwa treatment ke 5-8 efektif untuk meningkatkan kesadaran akan respek pada siswa SD. Hal ini dibuktikan dengan adanya peningkatan skor kesadaran akan respek pada seluruh subjek. Dari sepuluh subjek penelitian, semua subjek menunjukkan adanya peningkatan skor hingga mencapai kriteria maksimal, yaitu "Sangat Tinggi". Hal ini dikarenakan pada saat pelancaran tes 3, siswa sudah memperoleh semua materi bacaan pada treatment biblioedukasi yaitu respek kepada diri dan juga respek kepada orang lain. Setelah membaca bacaan yang ada dalam biblioedukasi, subjek dapat menguji pikiran dan perilaku dirinya sendiri dari hasil mengidentifikasi pikiran dan perilaku tokoh dalam bacaan.

Biblioedukasi membantu subjek menganalisis pikiran dan perilaku yang berhubungan dengan diri dan orang lain (Anggraeni \& Khusumadewi, 2018), sehingga subjek telah mendapatkan pemahaman yang utuh dari semua materi yang telah dibaca (Gunawan \& Wulandari, 2017). Dari pemahaman tersebut kemudian terbentuklah kesadaran akan respek kepada diri dan orang lain. Kesadaran dapat muncul karena adanya informasi internal dan refleksi diri (Solso et al., 2005). Hal ini sejalan dengan pendapat bahwa biblioedukasi yang dilakukan secara intensif dapat memunculkan tindakan membaca, memahami, merefleksi serta menginternalisasi materi bacaan kedalam kehidupan sehari-sehari (Eliasa, 2011). Dengan adanya kesadaran tersebut, individu mampu menginternalisasikan pemahaman yang telah diperoleh selama pemberian treatment ke dalam kehidupan sehari-hari. Beberapa penelitian telah membuktikan bahwa biblioedukasi atau disebut juga biblioterapi dapat menangani berbagai permasalahan yang dialami siswa (Anggraeni \& Khusumadewi, 2018; Fauziyah, 2015; Marantika, Setyawati, \& Krisphianti, 2018; Munawaroh \& Sofyan, 2018; Setiowati \& Wimbarti, 2014). 


\section{Simpulan}

Berdasarkan hasil penelitian, terdapat perbedaan kesadaran akan respek siswa antara sebelum dan sesudah diberikan treatment berupa biblioedukasi. Hal ini ditunjukkan dengan adanya perbedaan hasil antara pretest (tes 1) dan hasil posttest (tes 3 ) pada uji beda kesadaran akan respek. Walaupun pada saat dilihat hasil analisis di tiap empat kali pemberian treatment, terdapat empat treatment yaitu treatment ke 1-4 yang menyatakan tidak memberikan pengaruh untuk meningkatkan kesadaran respek siswa. Namun, secara umum dapat dinyatakan bahwa biblioedukasi dapat meningkatkan kesadaran akan respek siswa SD. Berdasarkan hasil penelitian, diharapkan guru SD dapat memanfaatkan bibliedukasi sebagai salah satu strategi alternatif untuk meningkatkan kesadaran respek siswa SD.

\section{Daftar Rujukan}

Anggraeni, A., \& Khusumadewi, A. (2018). Biblioterapi untuk meningkatkan pemahaman labelling negatif pada siswa SMP. Bikotetik (Bimbingan Dan Konseling: Teori dan Praktik), 2(1), 109-114.

Eliasa, E. I. (2011). Bibliotherapy as a method of meaningful treatment.

Fauziyah, L. (2015). Keefektifan biblioterapi dalam meningkatkan kemandirian belajar peserta didik kelas XIPS 2 di MA Sunan Kalijogo tahun pelajaran 2013/2014. Simki Pedagogia.

Gunawan, I. M., \& Wulandari, J. (2017). Pengaruh teknik biblioterapi terhadap kesadaran diri siswa. Jurnal Kependidikan: Jurnal Hasil Penelitian dan Kajian Kepustakaan di Bidang Pendidikan, Pengajaran dan Pembelajaran, 3(1).

Herlina, H. (2013). Bibliotherapy: Mengatasi masalah anak dan remaja melalui buku. Bandung: Pustaka Cendikia Utama.

Kamaningtyas, N. (2012). Keefektifan bibliokonseling untuk meningkatkan kesadaran toleransi siswa SMP. Universitas Negeri Malang.

Karang, A. M. (2018). Berawal dari kehilangan buku, siswa SD di Garut duel, satu tewas. Retrieved February 25, 2019, from https://regional.kompas.com/read/2018/07/24/14145451/berawal-darikehilangan-buku-siswa-sd-di-garut-duel-satu-tewas

Kemendikbud. Undang-undang Republik Indonesia No. 20 Pasal 3 Tahun 2003 (2003).

Kemendikbud. (2016). Pedoman bimbingan dan konseling pada pendidikan dasar dan pendidikan menengah. Jakarta: Kementerian Pendidikan dan Kebudayaan Republik Indonesia.

Lickona, T. (2009). Educating for character: How our schools can teach respect and responsibility. Bantam.

Marantika, S., Setyawati, S. P., \& Krisphianti, Y. D. (2018). Keefektifan teknik biblioterapi untuk meningkatkan karakter hormat pada siswa kelas XI di SMK PGRI 4 Kediri. Simki Pedagogia, 2(4), 1-8.

Masri, S. (2016). Keefektifan teknik bibliotherapy dan cinemeducation terhadap peningkatan multicultural awareness siswa SMA. Universitas Negeri Malang.

Mufidah, I. (2011). Keefektifan bibliokonseling untuk meningkatkan kesadaran bertanggung jawab siswa SMP. Universitas Negeri Malang.

Munawaroh, E., \& Sofyan, A. (2018). Keefektifan Biblioterapi untuk meningkatkan resiliensi siswa yatim piatu penghuni panti asuhan. Jurnal Kajian Bimbingan dan Konseling, 3(4), 154-161.

Sangaji. (2019). Akibat gol bunuh diri, siswa SD dianiaya. Retrieved February 25, 2019, from https://www.liputan6.com/news/read/3242167/video-akibat-gol-bunuh-diri-siswa-sd-dianiaya

Setiowati, E. A., \& Wimbarti, S. (2014). The effect of group bibliotherapy in reducing social anxiety of gifted and talented adolescents. Anima, Indonesian Psychological Journal, 29(4), 207-220.

Solso, R. L., MacLin, M. K., \& MacLin, O. H. (2005). Cognitive psychology. Pearson Education New Zealand. 